\title{
Aggregated, Wild-Type Prion Protein Causes Neurological Dysfunction and Synaptic Abnormalities
}

\author{
Roberto Chiesa, ${ }^{1}$ Pedro Piccardo, ${ }^{2,3}$ Emiliano Biasini, ${ }^{1,4}$ Bernardino Ghetti, ${ }^{2}$ and David A. Harris ${ }^{4}$ \\ ${ }^{1}$ Dulbecco Telethon Institute and Department of Neuroscience, Istituto di Ricerche Farmacologiche Mario Negri, 20156, Milan, Italy, ${ }^{2}$ Indiana Alzheimer \\ Disease Center, Indiana University School of Medicine, Indianapolis, Indiana 46202, ${ }^{3}$ Center for Biologics Evaluation and Research, Food and Drug \\ Administration, Rockville, Maryland 20852, and ${ }^{4}$ Department of Cell Biology and Physiology, Washington University School of Medicine, St. Louis, \\ Missouri 63110
}

The neurotoxic forms of the prion protein $(\operatorname{PrP})$ that cause neurodegeneration in prion diseases remain to be conclusively identified. Considerable evidence points to the importance of noninfectious oligomers of PrP in the pathogenic process. In this study, we describe lines of $\operatorname{Tg}(\mathrm{WT})$ transgenic mice that over-express wild-type PrP by either $\sim 5$-fold or $\sim 10$-fold (depending on whether the transgene array is, respectively, hemizygous or homozygous). Homozygous but not hemizygous $\mathrm{Tg}(\mathrm{WT})$ mice develop a spontaneous neurodegenerative illness characterized clinically by tremor and paresis. Both kinds of mice accumulate large numbers of punctate PrP deposits in the molecular layer of the cerebellum as well as in several other brain regions, and they display abnormally enlarged synaptic terminals accompanied by a dramatic proliferation of membranous structures. The over-expressed $\mathrm{PrP}$ in $\mathrm{Tg}(\mathrm{WT})$ mice assembles into an insoluble form that is mildly protease-resistant and is recognizable by aggregation-specific antibodies, but that is not infectious in transmission experiments. Together, our results demonstrate that noninfectious aggregates of wild-type $\operatorname{PrP}$ are neurotoxic, particularly to synapses, and they suggest common pathogenic mechanisms shared by prion diseases and nontransmissible neurodegenerative disorders associated with protein misfolding.

Key words: prion; transgenic; protein aggregation; synapse; wild-type; neurodegeneration

\section{Introduction}

Prion diseases, or transmissible spongiform encephalopathies, are fatal neurodegenerative disorders that affect humans and animals (Prusiner, 2004; Aguzzi et al., 2008). A central event associated with these diseases is the conformational conversion of the cellular prion protein $\left(\mathrm{PrP}^{\mathrm{C}}\right)$ into a $\beta$-rich isoform $\left(\mathrm{PrP}^{\mathrm{Sc}}\right)$ that has the properties of an infectious protein (Prusiner, 1998).

The mechanism by which conversion of $\operatorname{PrP}^{\mathrm{C}}$ into $\operatorname{PrP}^{\mathrm{Sc}}$ causes neurodegeneration remains unclear (Chiesa and Harris, 2001). PrP knock-out mice do not develop symptoms of prion disease, indicating that pathogenesis is not simply due to loss of $\operatorname{PrP}^{\mathrm{C}}$ function upon conversion to $\operatorname{PrP}^{\mathrm{Sc}}$ (Büeler et al., 1992; Manson et al., 1994; Mallucci et al., 2002). Intriguingly, neuronal expression of GPI-anchored $\mathrm{PrP}^{\mathrm{C}}$ is required for development of

Received July 4, 2008; revised 0ct. 3, 2008; accepted 0ct. 17, 2008.

This work was supported by grants from the National Institutes of Health to D.A.H. (NS040975) and B.G. (P30 AG010133); and from Telethon-Italy to R.C. (TCR05006) and E.B. (Fellowship GFP04007). R.C. is an Assistant Telethon Scientist (Dulbecco Telethon Institute, Fondazione Telethon). The findings and conclusions in this article have not been formally disseminated by the Food and Drug Administration and should not be construed to represent any Agency determination or policy. We thank Richard Kascsak for 3F4 and 6D11 antibodies, Man-Sun Sy for 8H4 antibody, and Alex Raeber and Bruno Oesch from Prionics (Zurich, Switzerland) for $15 B 3$ antibody. We are grateful to Assunta Senatore for help with Western blot quantification; Cheryl Adles and Su Deng for mouse colony maintenance and genotyping; and Rose Richardson and Constance Alyea for preparation of histological specimens.

Correspondence should be addressed to either of the following: Roberto Chiesa, Dulbecco Telethon Institute and Department of Neuroscience, Istituto di Ricerche Farmacologiche Mario Negri, Via G. La Masa 19, 20156, Milan, Italy, E-mail: chiesa@marionegri.it; or David A. Harris, Department of Cell Biology and Physiology, Washington University School of Medicine, 660 South Euclid Avenue, St. Louis, M0 63110, E-mail: dharris@wustl.edu.

DOI:10.1523/JNEUROSCI.3109-08.2008

Copyright $\odot 2008$ Society for Neuroscience ～0270-6474/08/2813258-10\$15.00/0 prion-induced neurodegeneration (Brandner et al., 1996; Mallucci et al., 2003; Chesebro et al., 2005), suggesting that when $\operatorname{PrP}^{\mathrm{C}}$ misfolds it produces a neurotoxic stimulus, possibly as a consequence of oligomerization of $\operatorname{PrP}^{\mathrm{C}}$ on the cell surface and/or abnormal interaction with an unknown transducing partner (Solforosi et al., 2004; Harris and True, 2006; Li et al., 2007). Some forms of prion disease develop in the apparent absence of infectious PrP ${ }^{\text {Sc }}$ (Hegde et al., 1999; Barron et al., 2007; Piccardo et al., 2007), suggesting that molecular species of PrP distinct from $\mathrm{PrP}^{\mathrm{Sc}}$ may represent the primary neurotoxic culprits (Chiesa and Harris, 2001).

There is evidence that in prion disorders, as well as in other neurodegenerative diseases, neurotoxicity is induced by small, $\beta$-rich oligomers, rather than by large amyloid polymers. For example, we previously found that transgenic mice expressing mouse PrP carrying a 9-octapeptide insertion (PG14) associated with an inherited prion disease accumulate in their brains a weakly aggregated, $\beta$-sheet-rich form of the mutant protein (Chiesa et al., 1998; Chiesa et al., 2000). This form is highly neurotoxic, but differs from $\operatorname{PrP}^{\mathrm{Sc}}$ because it lacks detectable infectivity (Chiesa et al., 2003; Biasini et al., 2008a). A biochemically similar pathogenic form of misfolded $\mathrm{PrP}$ was also found in $\operatorname{Tg}(\mathrm{MoPrP}-\mathrm{P} 101 \mathrm{~L})$ mice, which overexpress the mouse PrP homolog of the P102L mutation linked to Gerstmann-SträusslerScheinker (GSS) disease (Nazor et al., 2005), and in transgenic mice expressing the mouse PrP homolog of the D178N/V129 mutation linked to familial CJD (Dossena et al., 2008). There is 
now abundant evidence that small, misfolded oligomers of $\mathrm{A} \beta$ play a crucial pathogenic role in Alzheimer's disease, possibly by damaging synaptic structure or impairing synaptic function (Haass and Selkoe, 2007). Similar aggregates are likely to be involved in other, noninfectious neurodegenerative disorders, including Huntington's disease, Parkinson's disease, and tauopathies (Friedhoff et al., 1998; Lashuel et al., 2002; Marchut and Hall, 2006).

We now report that an aggregated, neurotoxic PrP isoform is spontaneously produced in transgenic mice expressing high levels of wild-type PrP. These mice develop a neurodegenerative syndrome characterized clinically by tremor and paralysis of the hind limbs, and neuropathologically by coarse PrP deposits and dramatic synaptic alterations in the cerebellar molecular layer. The phenotype of these mice defines a new neurodegenerative illness caused by aggregation of wild-type PrP. Our results support the concept that infectivity and pathogenicity are distinct features of abnormal PrP, underscoring the similarity between prion diseases and nontransmissible neurodegenerative disorders of protein conformation.

\section{Materials and Methods}

Transgenic mice. We have previously described production of transgenic mice expressing either wild-type mouse $\operatorname{PrP}(\mathrm{Tg}(\mathrm{WT})$, lines E1, E3 and E4) or mouse PrP harboring a nine-octapeptide insertion ( $\mathrm{Tg}$ (PG14), lines A2 and A3), both tagged with an epitope for the monoclonal antibody 3F4 (Chiesa et al., 1998). These mice were generated on a C57BL/ $6 \mathrm{~J} \times \mathrm{CBA} / \mathrm{J}$ background, and were subsequently bred either with $\mathrm{C} 57 \mathrm{BL} /$ $6 \mathrm{~J} \times \mathrm{CBA} / \mathrm{J}$ mice, or with Zürich I Prnp ${ }^{0 / 0}$ mice $(\mathrm{C} 57 \mathrm{BL} / 6 \mathrm{~J} \times 129$ background) (Büeler et al., 1992). The presence and zygosity of the transgenes were determined by PCR and Southern blot analysis as previously described (Chiesa et al., 1998).

Mice were observed weekly for signs of neurological dysfunction according to a set of objective criteria (Chiesa et al., 1998). Onset of neurological disease in $\mathrm{Tg}\left(\mathrm{WT}-\mathrm{E} 3^{+/+}\right)$mice was scored as the time at which tremor was first observed.

Biochemical assays. Brain homogenates were prepared in PBS containing either $0.5 \% \mathrm{NP}-40$ and $0.5 \%$ sodium deoxycholate, or $0.5 \%$ SDS, using a Teflon/glass tissue homogenizer. In some experiments, a proteinase inhibitor mixture (pepstatin and leupeptin, $1 \mu \mathrm{g} / \mathrm{ml}$; phenylmethylsulphonyl fluoride, $0.5 \mathrm{~mm}$; EDTA, $2 \mathrm{~mm}$ ) was added to the homogenization buffer. Assays of detergent-insolubility and proteinase K (PK) resistance $\left(37^{\circ} \mathrm{C}\right)$ were performed as described previously (Chiesa et al., 1998). Cold PK resistance assays were performed as described (Tremblay et al., 2004). Immunoprecipitation with antibody $15 B 3$ (Prionics, $\mathrm{CH}$ ) was performed as described (Biasini et al., 2008b).

Western blots were developed with monoclonal antibodies (mAbs) 3F4, (Kascsak et al., 1987), 6D11 (Pankiewicz et al., 2006), or 8H4 (Zanusso et al., 1998); or with polyclonal antibody P45-66 (Lehmann and Harris, 1995). mAb 3F4 selectively recognizes PrP encoded by the transgenes, while the other antibodies detect both transgenically encoded and endogenous mouse PrP. Actin was detected with monoclonal antibody C4 (Millipore Bioscience Research Reagents). After incubation with primary antibodies, blots were probed with anti-rabbit or anti-mouse IgG peroxidase-conjugated antibodies (Santa Cruz Biotechnology) and developed by enhanced chemiluminescence (ECL Plus, GE Healthcare). For quantification of PrP expression, the chemiluminescent signal was digitized with a CCD camera (ChemiDoc XRS, Bio-Rad), and band intensities were analyzed by Quantity One Software 4.6.2 (Bio-Rad). Signals were confirmed to be in the linear range.

DNA laddering was assessed as described (Chiesa et al., 2000).

Light microscopy. Animals were anesthetized with sodium pentobarbital $(50 \mathrm{mg} / \mathrm{kg}$, i.p.) and perfused transcardially with $10 \mathrm{ml}$ of normal saline, followed by $60-120 \mathrm{ml}$ of $4 \%$ paraformaldehyde in $0.1 \mathrm{M}$ phosphate buffer, $\mathrm{pH}$ 7.2. Brains were removed and postfixed in the same fixative for 30-60 min. The brains were hemisected along the midline, and the two halves (including the cerebral and cerebellar hemispheres, and brainstem) were dehydrated in graded ethanol solutions, cleared in xylene, and embedded in paraffin. Eight-micrometer sagittal sections were cut and mounted on polylysine-coated slides. Some sections were stained with hematoxylin and eosin, and some with thioflavin S.

For detection of glial fibrillary acidic protein (GFAP), sections were stained with an antibody from Biogenex at 1:50 dilution, followed by visualization using the peroxidase-anti-peroxidase (PAP) method with goat anti-rabbit IgG and rabbit PAP (Sternberger Monoclonals). 3,3' diaminobenzidine was used as a chromogen. Sections were sometimes lightly counterstained with hematoxylin to reveal the location of cells.

For PrP immunohistochemistry, sections were pretreated with $3 \mathrm{M}$ guanidine thiocyanate, followed by hydrolytic autoclaving using $0.75 \mathrm{~mm}$ $\mathrm{HCl}$ for $20 \mathrm{~min}$. Staining was performed using either mAb 3F4 (1:250) to detect exclusively transgenic PrP, or a rabbit antibody raised against human PrP residues 95-108 (identical to mouse PrP residues 94-107) $(1: 100)$ to detect both transgenic and endogenous PrP. Visualization was accomplished as above, using goat anti-mouse or anti-rabbit IgG, and mouse or rabbit PAP.

Electron microscopy. Following heparinization (500 USP units intraperitoneally) and pentobarbital sodium anesthesia (50 mg/kg i.p.), mice were perfused transcardially, first with $4 \%$ formaldehyde in $0.1 \mathrm{~m}$ phosphate buffer adjusted to $\mathrm{pH} 7.4$, and subsequently with $5 \%$ glutaraldehyde in the same buffer. After dissection, the cerebrum, cerebellum and brainstem were sliced. Slices were impregnated with Dalton's chrome osmium for $2 \mathrm{~h}$, dehydrated in graded ethanol solutions, passed through propylene oxide, and embedded in Epon. Semithin sections $(1 \mu \mathrm{m})$ were stained with Toluidine Blue for light microscopy. Ultrathin sections were stained with uranyl acetate and lead citrate and examined in a Philips 300 electron microscope.

\section{Results}

\section{Transgenic mice over-expressing wild-type PrP develop a neurological illness}

We previously established three transgenic mouse lines overexpressing epitopically tagged wild-type PrP derived from the mouse Prnp ${ }^{a}$ allele [Tg(WT) lines E1, E3 and E4] (Chiesa et al., 1998). Mice from each of these lines that carried the transgene array in a hemizygous state developed normally and did not show any neurological dysfunction as they aged (Chiesa et al., 1998). $\mathrm{Tg}(\mathrm{WT})$ mice of each line were subsequently interbred to render the transgene array homozygous and analyzed for the presence of neurological symptoms. We observed that homozygous mice of the $\operatorname{Tg}(\mathrm{WT}-\mathrm{E} 3)$ line, which displayed the highest level of $\operatorname{PrP}$ expression in the brain (see below), developed a progressive neurological illness, the earliest symptom of which was a tremor that was apparent when the mice initiated walking. This symptom was followed by the appearance of kyphosis, ataxia and paresis of the hind limbs, which increased in severity to total paralysis as the mice aged (Fig. 1). Animals in the advanced stage of the disease showed dramatic thinning of the posterior part of the trunk, reduced body weight, ruffled coat due to poor grooming, and inability to right themselves from a supine position (Fig. 1). The animals were humanely killed when they became unable to feed themselves.

The mean age of onset of the neurological signs in $\mathrm{Tg}$ (WT$\left.\mathrm{E} 3^{+/+}\right) / \operatorname{Prnp}^{0 / 0}$ mice was $159 \pm 23 \mathrm{~d}$ and the mean age at death was $409 \pm 42 \mathrm{~d}$ (Fig. 2). The duration of the symptomatic phase of the illness was quite prolonged $(250 \pm 32 \mathrm{~d})$ (Fig. 2). In three $\mathrm{Tg}\left(\mathrm{WT}_{-\mathrm{E}}{ }^{+/+}\right)$mice on the Prnp ${ }^{+/+}$background that we analyzed, the mean age of disease onset was $161 \pm 1 \mathrm{~d}$.

Significantly, neurological symptoms developed only in $\operatorname{Tg}\left(\right.$ WT-E3 $\left.{ }^{+/+}\right)$mice that were homozygous for the transgene array. $\mathrm{Tg}\left(\mathrm{WT}-\mathrm{E} 3^{+/-}\right)$mice have remained healthy for $>750 \mathrm{~d}$. In addition, no neurological abnormalities were observed in homozygous $\operatorname{Tg}(\mathrm{WT})$ mice of the E1 and E4 lines, which overexpressed wild-type PrP at lower levels (see below). 


\section{Analysis of PrP levels in brain}

We previously determined the level of transgenically encoded PrP relative to endogenous PrP by Western blotting of postnuclear supernatants from brain, using the antibody 3F4 (Chiesa et al., 1998). We have now performed a more accurate analysis of transgenic PrP expression by comparing the levels of PrP in the brains of $\mathrm{Tg}$ (WT-E3) mice to those in nontransgenic $\mathrm{C} 57 \mathrm{BL} / 6 \mathrm{~J} \times \mathrm{CBA} / \mathrm{J}$ mice as well as Tga20 mice that over-express nonepitopically tagged, wild-type $\operatorname{PrP}$ (Fischer et al., 1996). For these quantitative Western blots, we used 3F4 antibody, as well as an antibody directed against mouse PrP residues 45-66 that recognizes both transgenic and endogenous PrP. Moreover, to reduce the variability associated with the preparation of postnuclear supernatants, we analyzed whole brain SDS extracts, and normalized the PrP signal to the level of actin. This analysis demonstrated that $\mathrm{Tg}\left(\mathrm{WT}_{-} \mathrm{E} 3^{+/+}\right)$mice were the highest expressers, with brain PrP levels that were 9- or 12-fold higher than those in nontransgenic mice, depending on whether the mice had the $\operatorname{Prnp} p^{0 / 0}$ or Prnp ${ }^{+/+}$background, respectively (Fig. 3). Tg(WTE ${ }^{+/-}$) mice had PrP expression levels of 4 times and 7 times on the $\operatorname{Prnp}^{0 / 0}$ and $\operatorname{Prnp}^{+/+}$backgrounds, respectively (Fig. 3 ).

With regard to the other $\mathrm{Tg}(\mathrm{WT})$ lines, we found that $\mathrm{Tg}(\mathrm{WT}$ $\mathrm{E} 1^{+/+}$) mice expressed 3.6-fold more PrP than wild-type mice (data not shown), consistent with our previous analysis showing a PrP expression level of $\sim 1.8$ times in $\mathrm{Tg}\left(\mathrm{WT}-\mathrm{E} 1^{+/-}\right)$mice (Chiesa et al., 1998). In the $\mathrm{Tg}(\mathrm{WT}-\mathrm{E} 4)$ line, the transgene was present on the $\mathrm{X}$-chromosome, so that the only mice that were homozygous for the transgene were female. Due to $\mathrm{X}$-inactivation, these animals had a PrP expression level (3 times) similar to that of both male and female $\mathrm{Tg}\left(\mathrm{WT}-\mathrm{E} 4^{+/-}\right)$mice (data not shown). Thus, mice with PrP expression levels of 1.8-7 times remain healthy, while those with expression levels of 9-12 times develop neurological symptoms.

$\operatorname{PrP}$ in $\operatorname{Tg}(\mathrm{WT}-\mathrm{E} 3)$ mice is mildly protease resistant and forms insoluble aggregates that are recognized by an aggregationspecific antibody

We previously reported that the development of neurological illness in $\mathrm{Tg}$ (PG14) mice is associated with accumulation in the brain of a noninfectious form of mutant PrP that is insoluble in nondenaturing detergents, and that yields a $27-30 \mathrm{kDa}$ proteaseresistant fragment upon digestion with low concentrations of PK (Chiesa et al., 1998, 2000, 2003). We therefore tested whether $\mathrm{Tg}$ (WT-E3) mice accumulated an analogous form of WT PrP that was aggregated and weakly protease-resistant.

To test PrP solubility, detergent extracts of brain were subjected to ultracentrifugation and the amount of PrP in the supernatant and pellet fractions was evaluated by Western blot. As shown in Figure 4A (lanes 3-6), a small percentage of $\operatorname{PrP}$ was recovered in the pellet fraction of brain extracts from both $\mathrm{Tg}\left(\mathrm{WT}_{-\mathrm{E}} 3^{+/+}\right)$and $\mathrm{Tg}\left(\mathrm{WT}-\mathrm{E} 3^{+/-}\right)$mice. In contrast, virtually no detergent-insoluble $\operatorname{PrP}$ was found in brain samples from nontransgenic mice expressing physiological levels of PrP (Fig. 4 A, lanes 1-2). The proportion of insoluble PrP was consistently higher in $\mathrm{Tg}\left(\mathrm{WT}_{-} \mathrm{E} 3^{+/+}\right)$mice than in $\mathrm{Tg}\left(\mathrm{WT}-\mathrm{E} 3^{+/-}\right)$mice $(5 \%$

\begin{tabular}{lll}
\hline Clinical Illness in Tg(WT-E3 & \\
\hline Age at onset & $159 \pm 23$ & $(102-285)$ \\
Age at death & $409 \pm 42$ & $(238-514)$ \\
Duration of illness & $250 \pm 32$ & $(107-362)$ \\
\hline
\end{tabular}

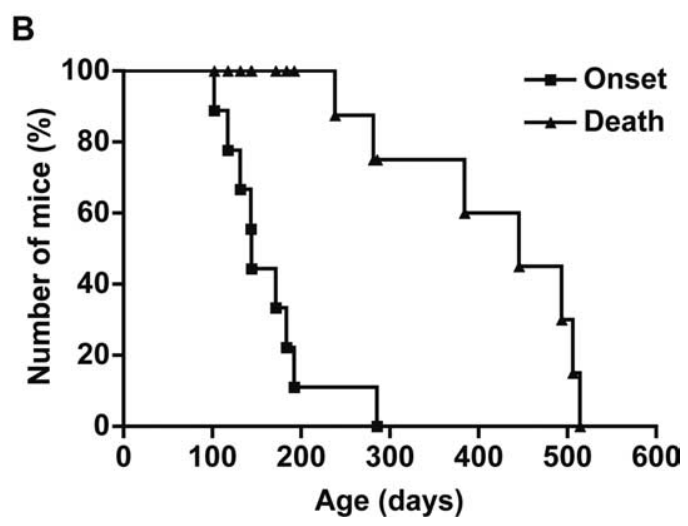

Figure 2. Clinical illness in $\mathrm{Tg}\left(\mathrm{WT}-\mathrm{E} 3^{+/+}\right) / \mathrm{Prnp}^{0 / 0}$ mice. $\boldsymbol{A}$, Tabulation of age at onset, age at death, and duration of illness. Entries show the mean number of days \pm SEM for a cohort of 7 mice, with the range given in parentheses. $\boldsymbol{B}$, Symptom onset and survival curves for a total of 9 and 7 mice, respectively.

compared with 10\%). As expected, $\sim 40 \%$ of the PrP from the brains of $\operatorname{Tg}(\mathrm{PG} 14)$ mice was found in the pellet fraction (Fig. $4 \mathrm{~A}$, lanes 7-8).

We have recently shown that the mAb 15B3, originally thought to specifically recognize $\operatorname{PrP}^{\mathrm{Sc}}$, also detects a variety of misfolded and aggregated forms of PrP, including mutant PrP in the brains of $\operatorname{Tg}(\mathrm{PG} 14)$ mice (Biasini et al., 2008a, 2008b). We therefore tested whether $15 \mathrm{~B} 3$ reacted with WT PrP aggregates in $\mathrm{Tg}$ (WT-E3) mice. We found that 15B3 selectively immunoprecipitated the small amount of $\operatorname{PrP}$ found in the insoluble fractions of $\mathrm{Tg}(\mathrm{WT}-\mathrm{E} 3)$ brain homogenates (Fig. $4 \mathrm{~B}$, lanes 4 and 6). The much larger amount of soluble PrP found in the supernatant 


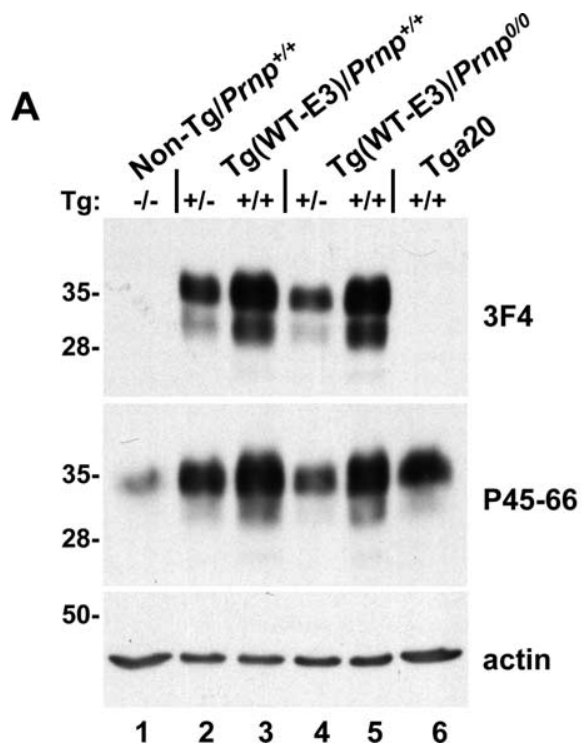

B

Figure 3. PrP expression in mouse brains. A, Brain extracts ( $20 \mu \mathrm{g}$ of total protein) were separated by SDS-PAGE and immunoblotted with monoclonal antibody 3F4 which recognizes only transgenically encoded PrP (top), antibody P45-66 which recognizes both endogenous and transgenically encoded PrP (middle), or a monoclonal antibody directed against actin (bottom). The genotypes and ages of the mice were as follows: Non-Tg/Prnp ${ }^{+/+}$(C57BL/6J $\times(B A / J)$, 291-d-old (lane 1); Tg(WT-E3)/ Prnp $^{+1+}, 247-\mathrm{d}$-old, hemizygous (lane 2) or homozygous (lane 3); $\operatorname{Tg}\left(\right.$ WT-E3)/Prnp ${ }^{0 / 0}, 202$-d-old, hemizygous (lane 4) or homozygous (lane 5); Tga $20^{+/+} /$Prnp $^{0 / 0}, 148$-d-old (lane 6). B, The amount of total PrP (endogenous plus transgenic) in each mouse line was quantitated by densitometric analysis of the Western blot shown in $A$, middle. The PrP signal was normalized for the level of actin (bottom panel). Molecular size markers are given in $\mathrm{kDa}$. The results are representative of two independent experiments.

A

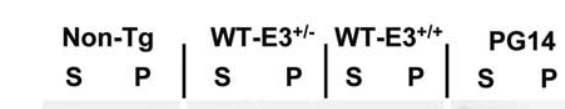

37-

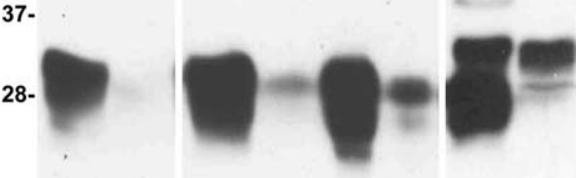

18-

$$
\begin{array}{llllllll}
1 & 2 & 3 & 4 & 5 & 6 & 7 & 8
\end{array}
$$

B

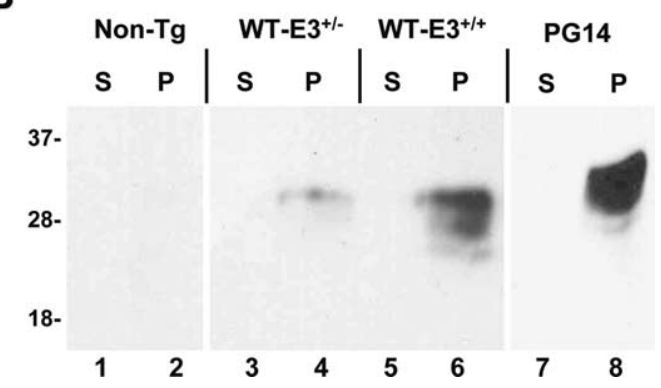

Figure 4. A fraction of PrP in the brains of $\mathrm{Tg}(\mathrm{WT}-\mathrm{E} 3)$ mice is insoluble and can be immunoprecipitated by $15 B 3$ antibody. $A$, Brain lysates prepared from mice of the following genotypes and ages were subjected to ultracentrifugation at $186,000 \times g$ for $40 \mathrm{~min}$, and PrP in the supernatants ( $S$ lanes) and pellets ( $P$ lanes) was analyzed by Western blotting using 6D11 antibody: non-Tg/Prnp ${ }^{+/+}, 156 \mathrm{~d}$ (lanes 1-2); $\operatorname{Tg}\left(\right.$ WT-E3 $\left.{ }^{+/-}\right) /$Prnp $^{0 / 0}, 162 \mathrm{~d}$ (lanes 3-4); $\mathrm{Tg}\left(\mathrm{WT}^{-E 3^{+/+}}\right) / \mathrm{Prnp}^{0 / 0}, 162 \mathrm{~d}$ (lanes 5-6); $\mathrm{Tg}\left(\mathrm{PG} 14^{+/-}\right) / \mathrm{Prnp}^{0 / 0}, 156 \mathrm{~d}$ (lanes 7-8). B, Supernatant and pellet fractions obtained in $B$ were subjected to immunoprecipitation using the monoclonal antibody 15B3. Immunoprecipitated PrP was analyzed by Western blotting with antibody $8 \mathrm{H} 4$. fractions from these animals was not recognized (Fig. $4 B$, lanes 3 and 5 ). The amount of 15B3-reactive $\operatorname{PrP}$ was greater in $\mathrm{Tg}(\mathrm{WT}$ $\left.\mathrm{E}^{+/+}\right)$mice than in $\mathrm{Tg}\left(\mathrm{WT}^{+\mathrm{E}} 3^{+/-}\right)$mice, paralleling the larger amount of insoluble $\mathrm{PrP}$ in the former animals. As a negative control, no 15B3-reactive PrP was detected in either the soluble or insoluble fractions from nontransgenic mice (Fig. 4B, lanes 1-2). Moreover, as found previously (Biasini et al., 2008a, 2008b), insoluble PrP in the brains of $\mathrm{Tg}$ (PG14) mice was selectively immunoprecipitated by $15 B 3$ (Fig. 4B, lanes 7-8).

Resistance to digestion by $\mathrm{PK}$ is another property of aggregated $\operatorname{PrP}$ (Chiesa et al., 2003; Biasini et al., 2008a). To assay this property, detergent extracts of brain were incubated with $1-3 \mu \mathrm{g} / \mathrm{ml} \mathrm{PK}$ at $37^{\circ} \mathrm{C}$ for $30 \mathrm{~min}$. We found that PrP from $\mathrm{Tg}(\mathrm{WT}-$ $\mathrm{E}^{+/+}$) mice was mildly PK resistant (Fig. $5 A$, lanes 6 and 14), yielding small amounts of a PrP27-30 fragment similar in size to that found in $\operatorname{Tg}$ (PG14) brains (Fig. 5A, lanes 17-24).

To better detect weakly PK-resistant $\mathrm{PrP}$, we performed the protease digestion assay at $4^{\circ} \mathrm{C}$, following a protocol that has been used to detect protease-resistant PrP in the brains of $\operatorname{Tg}(\mathrm{MoPrP}-\mathrm{P} 101 \mathrm{~L})$ mice (Tremblay et al., 2004). Using this assay, PK-resistant PrP could be readily visualized in brain samples from both $\operatorname{Tg}\left(\mathrm{WT}_{-\mathrm{E}}{ }^{+/-}\right)$and $\operatorname{Tg}\left(\mathrm{WT}-\mathrm{E} 3^{+/+}\right)$mice, with the amount being higher in the latter animals (Fig. 5B, lanes 6-10 and 11-15). A small amount of PrP was also detected after cold PK digestion of brain extracts from nontransgenic mice; however, this material corresponded to residual full-length $\operatorname{PrP}$ since it did not show a shift in molecular weight typical of PrP27-30 (Fig. 5B, lanes 1-5). As a positive control, PrP27-30 was also detected after PK digestion at $4^{\circ} \mathrm{C}$ of samples from $\mathrm{Tg}$ (PG14) brain (Fig. 5B, lanes 16-20).

\section{$\operatorname{Tg}$ (WT-E3) mice display punctate $\operatorname{PrP}$ deposits}

The most striking neuropathological feature seen in $\mathrm{Tg}$ (WT-E3) mice was the presence of numerous, coarse deposits of $\operatorname{PrP}$ in the molecular layer of the cerebellum, as revealed by PrP immunohistochemistry using two different antibodies. PrP deposits were seen in both healthy hemizygous animals (Fig. $6 E$ ) as well as clinically ill homozygous animals (Fig. $6 F, 7 B, D$ ); however, in homozygous mice they were more numerous and larger in diameter. Very mild and diffuse PrP immunoreactivity could be also detected in the granule cell layer (Figs. $6 F, 7 B, D$ ). Punctate PrP deposits were also seen in the olfactory bulb, neocortex, hippocampus, basal ganglia and brainstem, especially in homozygous mice (data not shown). PrP deposits were already evident in a $\mathrm{Tg}\left(\right.$ WT-E $3^{+/+}$) mouse that was 171 -d-old. None of the $\operatorname{PrP}$ deposits stained with thioflavin S (data not shown), indicating that they are not amyloid.

$\operatorname{PrP}$ deposits were not seen in non-Tg mice, even when the animals were very old (Fig. 7C). PrP immunoreactivity was occasionally found in older $\mathrm{Tg}\left(\mathrm{WT}-\mathrm{E} 1^{+/+}\right)$mice in the olfactory bulb, and in the cerebellar cortex at the level of the Purkinje cell layer (Fig. 6D). However, the degree of $\operatorname{PrP}$ deposition in 
$\operatorname{Tg}\left(\mathrm{WT}_{-} \mathrm{E}^{+/+}\right)$mice was much lower than in $\operatorname{Tg}(\mathrm{WT}-\mathrm{E} 3)$ mice, and was variable.

$\mathrm{Tg}\left(\mathrm{WT}_{-\mathrm{E}} 3^{+/+}\right)$mice also showed severe cerebellar atrophy, accompanied by marked reduction in the number of granule cells and thinning of the molecular layer (Fig. 6C). Milder cerebellar degeneration was seen also in $\mathrm{Tg}\left(\mathrm{WT}_{-\mathrm{E}}{ }^{+/-}\right)$ mice, which displayed moderate reduction in thickness of the cerebellar cortex compared with $\operatorname{Tg}\left(\mathrm{WT}-\mathrm{E} 1^{+/+}\right)$mice (Fig. 6, compare $B$ and $A$ ).

Immunohistochemical staining using anti-GFAP antibody demonstrated prominent astrocytosis, predominantly in the cerebellum, of $\mathrm{Tg}\left(\mathrm{WT}-\mathrm{E} 3^{+/+}\right)$mice, while astrocytosis was mild or absent in other areas showing PrP deposits. Staining was most prominent in the white matter (data not shown), and in the molecular layer, which displayed markedly hypertrophied Bergmann glial fibers (Fig. 6I). Less prominent GFAP staining was observed in the cerebellum of older $\mathrm{Tg}\left(\mathrm{WT}-\mathrm{E} 3^{+/-}\right)$and $\mathrm{Tg}\left(\mathrm{WT}_{-\mathrm{E}} 1^{+/+}\right)$mice, particularly in the Purkinje and granule cell layers (Fig. $6 G, H)$. However, similar GFAP immunoreactivity was also observed in older non-Tg mice (data not shown).

\section{$\mathrm{Tg}$ (WT-E3) mice show synaptic pathology}

Electron microscopic examination of the cerebella of both $\mathrm{Tg}\left(\mathrm{WT}_{-\mathrm{E}} 3^{+/+}\right)$and $\mathrm{Tg}\left(\mathrm{WT}^{\mathrm{E}} 3^{+/-}\right)$mice revealed two kinds of abnormalities. First, as expected from the light microscopic analysis, we observed degenerating granule neurons which displayed fragmented, osmiophilic nuclei characteristic of apoptosis (Fig. $8 A$ ). Second, prominent synaptic abnormalities were observed. The neuropil of the molecular layer contained synaptic terminals that were markedly enlarged, and contained redundant, spiral, membranous structures (Fig. 8B-E). These membranes surrounded mitochondria and large numbers of synaptic vesicles in the cytoplasm (Fig. 8C-E). Pre- and postsynaptic membrane specializations were well preserved, and collections of vesicles could be observed adjacent to the presynaptic membrane (Fig. $8 \mathrm{C}$, arrows).

\section{$\operatorname{Tg}(\mathrm{WT}-\mathrm{E} 3)$ mice show internucleosomal DNA cleavage in} the cerebellum

To confirm that neuronal degeneration in the cerebella of $\mathrm{Tg}$ (WT-E3) mice was apoptotic, as suggested by electron microscopic analysis (Fig. 8A), we checked for the presence of internucleosomal cleavage of DNA. When DNA was extracted from cerebella of $\mathrm{Tg}(\mathrm{WT}-\mathrm{E} 3)$ mice and analyzed by gel electrophoresis, a characteristic 200 base-pair ladder was observed in $\mathrm{Tg}$ (WT-E3) mice (Fig. 9). DNA laddering was less intense in $\mathrm{Tg}\left(\mathrm{WT}^{\mathrm{E}} 3^{+/-}\right.$) compared with $\operatorname{Tg}\left(\mathrm{WT}_{-\mathrm{E}} 3^{+/+}\right)$mice (compare lanes 4 and 6), consistent with the lower degree of cerebellar atrophy and granule cell loss observed in the hemizygous mice. In $\mathrm{Tg}\left(\mathrm{WT}-\mathrm{E} 1^{+/+}\right.$) no internucleosomal DNA cleavage was detected (Fig. 9, lane 2), whereas intense DNA laddering was observed in $\mathrm{Tg}(\mathrm{PG} 14)$ cerebella (lane 8), as previously reported (Chiesa et al., 2000, 2005).

\section{Discussion}

We have engineered transgenic mice that over-express wild-type mouse PrP by either $\sim 5$-fold or $\sim 10$-fold. Both kinds of mice accumulated large numbers of coarse PrP deposits in the cerebrum, cerebellum and brainstem, and showed dramatic proliferation of synaptic terminal membranes. Animals with the highest PrP levels developed a spontaneous neurodegenerative illness characterized clinically by tremor and paresis. The overexpressed PrP in these animals assumed an insoluble form that is mildly protease-resistant and recognizable by aggregationspecific antibodies (this work), but that is not infectious in transmission experiments (Chiesa et al., 2003). Together, these results demonstrate that noninfectious aggregates of wild-type PrP are neurotoxic, particularly to synapses, and they suggest common pathogenic mechanisms shared by prion diseases and nontransmissible neurodegenerative disorders associated with protein misfolding.

\section{Correlation between PrP over-expression, aggregation, and neurological disease}

Clinical symptoms developed in $\operatorname{Tg}\left(\mathrm{WT}-\mathrm{E} 3^{+/+}\right)$mice, whose PrP level in the brain was 9-12 times higher than in nontransgenic mice, and at least twice as much as the level in $\mathrm{Tg}$ (WT$\mathrm{E} 1^{+/+}$) or Tga20 mice, which remain healthy. The wild-type PrP coding sequence of the E3 transgene was confirmed by sequencing after PCR amplification of mouse tail DNA, ruling out the possibility that this molecular clone had spontaneously acquired pathogenic mutations. $\operatorname{Tg}\left(\mathrm{WT}_{-} \mathrm{E} 3^{+/-}\right)$mice, which had a $\operatorname{PrP}$ expression level 4-7 times higher than in nontransgenic animals, accumulated reduced numbers of PrP deposits in the cerebellum and displayed a smaller amount of aggregated $\mathrm{PrP}$ by biochemical assays, although these animals remained healthy. These results 

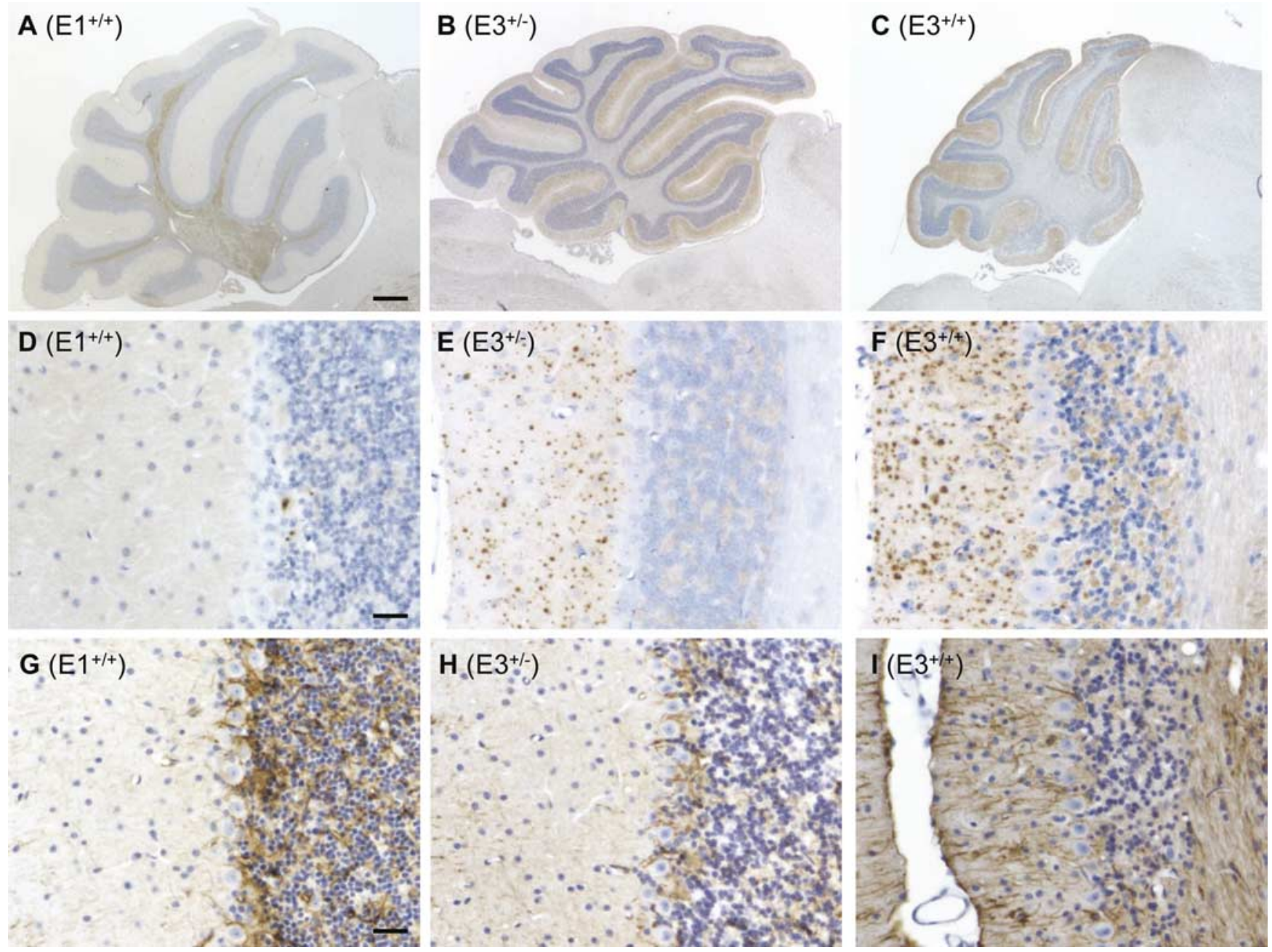

Figure 6. Neuropathological findings in the cerebella of Tg(WT-E3) mice. $\boldsymbol{A}-\boldsymbol{I}$, Sections of cerebellum were stained for PrP with $3 F 4$ antibody $(\boldsymbol{A}-\boldsymbol{F})$, or for GFAP $(\mathbf{G}-\boldsymbol{I})$. $\boldsymbol{A}, \mathrm{Cerebellum}$ of a healthy $\mathrm{Tg}\left(\mathrm{WT}-\mathrm{E} 1^{+/+}\right) /$Prnp $^{0 / 0}$ mouse at $451 \mathrm{~d}$ of age appears normal in size. Some PrP deposition is detected in the white matter. $\boldsymbol{B}$, Cerebellum of a healthy $\operatorname{Tg}\left(\mathrm{WT}-\mathrm{E} 3^{+/-}\right) / \mathrm{Prnp}^{0 / 0} \mathrm{mouse}$ at $348 \mathrm{~d}$ of age. There is moderate atrophy of the cerebellar cortex, with positive PrP staining in the molecular layer. C, Cerebellum of a terminally ill $\operatorname{Tg}\left(\mathrm{WT}-\mathrm{E} 3^{+/+}\right) / \mathrm{Prnp}^{0 / 0}$ mouse at $348 \mathrm{~d}$ of age. There is severe atrophy of the cerebellum with reduction in the thickness of the molecular and granule cell layers. PrP deposition is seen throughout the molecular layer. $\boldsymbol{D}$, Cerebellar cortex of the same mouse as shown in panel A. A few focal deposits of PrP are present. $\boldsymbol{E}$, Cerebellar cortex of a healthy $\mathrm{Tg}\left(\mathrm{WT}-\mathrm{E} 3^{+/-}\right) / \mathrm{Prnp}^{0 / 0}$ mouse at $514 \mathrm{~d}$ of age. There are numerous, punctate deposits of PrP in the molecular layer. $\boldsymbol{F}$, Cerebellar cortex of a terminally ill Tg(WT-E3 $\left.{ }^{+/+}\right) / P r n p^{0 / 0}$ mouse at $514 \mathrm{~d}$ of age. Larger and more numerous PrP deposits are seen in the molecular layer; some PrP deposition is also apparent in the granule cell layer. G, Cerebellar cortex of the same mouse shown in panel A. Positive staining for GFAP is visible in the granule and Purkinje cell layers, although this staining is similar to what is seen in non-Tg mice (data not shown). $\boldsymbol{H}$, Cerebellar cortex of the same mouse shown in panel E. Positive staining for GFAP is visible in the granule and Purkinje cell layers, similar to the mouse shown in panel G. I, Cerebellar cortex of the same mouse shown in panel F. There is intense GFAP staining throughout the cortex, with marked hypertrophy of Bergmann glial fibers in the molecular layer. Scale bars: (in $\boldsymbol{A}$ ) $\boldsymbol{A}-\boldsymbol{C}, 400 \mu \mathrm{m}$; (in $\boldsymbol{D}$ and $\mathbf{G}$ ) $\boldsymbol{D}-\boldsymbol{I}, 25 \mu \mathrm{m}$.

suggest a direct correlation between PrP expression level, PrP aggregation/cerebral deposition, and clinical illness. They also suggest that a threshold level of aggregated PrP is necessary to produce clinical symptoms, and that mice with a modest degree of PrP over-expression may accumulate insufficient aggregated $\operatorname{PrP}$ to cause overt neurological disease during their lifetimes. Consistent with this idea, we observed a small fraction of insoluble, 15B3-reactive $\operatorname{PrP}$ in $\operatorname{Tg} a 20$ and $\operatorname{Tg}\left(\mathrm{WT}_{-} \mathrm{E} 1^{+/+}\right.$) mice (data not shown). These mice never developed neurological symptoms, although $\mathrm{Tg}\left(\mathrm{WT}-\mathrm{E} 1^{+/+}\right)$mice did sometimes display mild PrP deposition in the cerebellum (Fig. 6A,D).

Although we have emphasized the idea that $\operatorname{PrP}$ aggregates are the cause of neurodegeneration in $\operatorname{Tg}$ (WT-E3) mice, it is also possible that high levels of PrP may be toxic in some other way, for example, by saturating or over-stimulating a normal metabolic or signaling pathway activated by $\operatorname{PrP}^{\mathrm{C}}$ (Westergard et al., 2007).

\section{Over-expressed wild-type PrP is aggregated and} conformationally altered, but is not infectious

A fraction of PrP in the brains of $\operatorname{Tg}$ (WT-E3) mice displayed biochemical features typical of $\mathrm{PrP}^{\mathrm{Sc}}$, such as insolubility in nondenaturing detergents, protease resistance (particularly at $4^{\circ} \mathrm{C}$ ), and reactivity with the aggregation-specific antibody $15 \mathrm{~B} 3$. These observations indicate that a subset of PrP molecules in $\mathrm{Tg}$ (WTE3) brains are conformationally altered in a way that distinguishes them from $\operatorname{PrP}^{\mathrm{C}}$. In previous experiments, we demonstrated that $\operatorname{Tg}(\mathrm{WT}-\mathrm{E} 3)$ brain homogenates failed to induce disease when inoculated intracerebrally into $\mathrm{CD} 1$ or $\mathrm{Tg}$ (WT-E1) mice (Chiesa et al., 2003). Thus, aggregates of wild-type PrP in $\operatorname{Tg}$ (WT-E3) mice, although associated with neuropathology, do not represent infectious $\mathrm{PrP}^{\mathrm{Sc}}$.

This dissociation of neurotoxicity and infectivity is also observed in $\operatorname{Tg}(\mathrm{PG} 14)$ mice which express PrP harboring a nine- 
octapeptide insertional mutation (Chiesa et al., 1998, 2000). These animals display a neurodegenerative phenotype accompanied by aggregation and cerebral deposition of a mildly protease-resistant and conformationally altered form of mutant PrP (Chiesa et al., 2003). Together, our studies of $\mathrm{Tg}$ (PG14) and $\mathrm{Tg}(\mathrm{WT}-\mathrm{E} 3)$ mice demonstrate that misfolded forms of $\mathrm{PrP}$ distinct from $\mathrm{PrP}^{\mathrm{Sc}}$ represent the primary pathogenic species in some prion diseases. We have referred to these noninfectious, neurotoxic forms collectively as $\mathrm{PrP}^{\text {toxic }}$ (Chiesa and Harris, 2001), and we have begun attempts to define how they differ structurally from $\mathrm{PrP}^{\mathrm{Sc}}$. Our studies of PG14 PrP indicate that although $\mathrm{PrP}^{\text {toxic }}$ and $\operatorname{PrP}^{\mathrm{Sc}}$ share a number of biochemical properties (Biasini et al., 2008a), one distinguishing feature lies in the size and compactness of the aggregates they form: $\mathrm{PrP}^{\text {toxic }}$ represents small, loosely packed oligomers consisting of $\sim 20-30$ PrP molecules, while $\mathrm{PrP}^{\mathrm{Sc}}$ is comprised of less easily dissociated aggregates containing several hundred PrP subunits (Chiesa et al., 2003). It will be interesting to see whether aggregates of wild-type PrP from $\mathrm{Tg}$ (WTE3) mice are structurally similar to aggregates of mutant PrP from Tg(PG14) mice.

\section{PrP aggregation and synaptic toxicity}

One striking neuropathological feature of $\mathrm{Tg}(\mathrm{WT}-\mathrm{E} 3)$ mice is the presence of abnormally enlarged synaptic terminals in the cerebellar molecular layer. These structures are composed of a proliferation of synaptic membranes enclosing mitochondria and synaptic vesicles. Several kinds of spiral membrane inclusions or invaginations have been described in neurons in the brains of scrapie-infected animals (Jeffrey et al., 2008), but these do not resemble the enlarged synaptic structures seen in $\mathrm{Tg}$ (WT-E3) mice. A number of observations indicate that synaptic alterations are early pathological signs of prion diseases, and an important determinant of symptomatology (Clinton et al., 1993; Ferrer et al., 2000; Jeffrey et al., 2000; Cunningham et al., 2003). Synapses are also a primary target of PG14 PrP aggregates (Chiesa et al., 2005).

How might over-expressed wild-type PrP cause synaptic pathology? One possibility is that PrP aggregates induced by overexpression may obstruct fast or slow axonal transport, thereby inhibiting delivery of proteins to synapses. We have proposed a similar mechanism to explain synaptic degeneration in $\mathrm{Tg}$ (PG14) mice (Medrano et al., 2008). Oligomerization of $\mathrm{PrP}$ at synaptic sites may also interfere with synaptic function. Consistent with this idea, synaptosomes isolated from $\mathrm{Tg}(\mathrm{PG} 14)$ cerebella show impaired depolarization-induced glutamate release (unpublished observations). It is also possible that, since $\operatorname{PrP}^{\mathrm{C}}$ is a normal constituent of synaptic membranes (Herms et al., 1999; Barmada et al., 2004), over-expression of the protein may somehow trigger proliferation of membranous components to accommodate the increased amount of PrP and associated molecules.

Recent studies have highlighted the synaptotoxic role of protein oligomers in other neurodegenerative diseases (Haass and Selkoe, 2007). For example, oligomeric A $\beta$ directly alters synaptic structure and function, and this phenomenon has been proposed to be a major pathogenic mechanism in Alzheimer's disease (Walsh et al., 2002; Kamenetz et al., 2003; Shankar et al., 2008). Together, these studies suggest that synapses may be particularly vulnerable to the toxic effects of protein oligomers, and that disrupting such oligomers may represent an effective therapeutic strategy for alleviating synaptic loss and neuronal dysfunction (Townsend et al., 2006). By identifying specific synaptic abnormalities induced by PrP aggregates, our results highlight important pathogenic similarities between prion diseases and other neurodegenerative disorders.

\section{Comparison with other mice over-expressing wild-type PrP}

A neurological illness has also been observed in several independent lines of transgenic mice over-expressing wild-type PrP from sheep, Syrian hamster, or mouse (Prnp ${ }^{b}$ allele) (Westaway et al., 1994). In each of these lines, transgene expression was driven by a Prnp cosmid from the corresponding species, and the degree of over-expression achieved was $\sim 7-8$-fold. Symptoms appeared late $(>450 \mathrm{~d})$, and included truncal ataxia, hind limb paralysis and tremors. Pathological abnormalities in these animals included focal CNS vacuolation, necrotizing myopathy, and demyelinating polyneuropathy. Of note, no cerebral PrP deposits similar to those displayed by $\mathrm{Tg}(\mathrm{WT}-\mathrm{E} 3)$ mice were detected in the CNS. Brain and muscle tissue from the mice described by Westaway et al. (1994) did not contain detectable amounts of $\mathrm{PrP}$ $27-30$ after digestion at $37^{\circ} \mathrm{C}$ with $20 \mu \mathrm{g} / \mathrm{ml}$ proteinase $\mathrm{K}$, although trace amounts of undigested $\operatorname{PrP}$ were visible. In light of our results with $\mathrm{Tg}$ (WT-E3) mice, we predict that a fraction of aggregated, misfolded PrP was likely present in those samples, and would have been revealed by cold PK digestion or $15 \mathrm{~B} 3$ immunoprecipitation.

In a second study, Huang et al. (2007) used a tetracycline- 

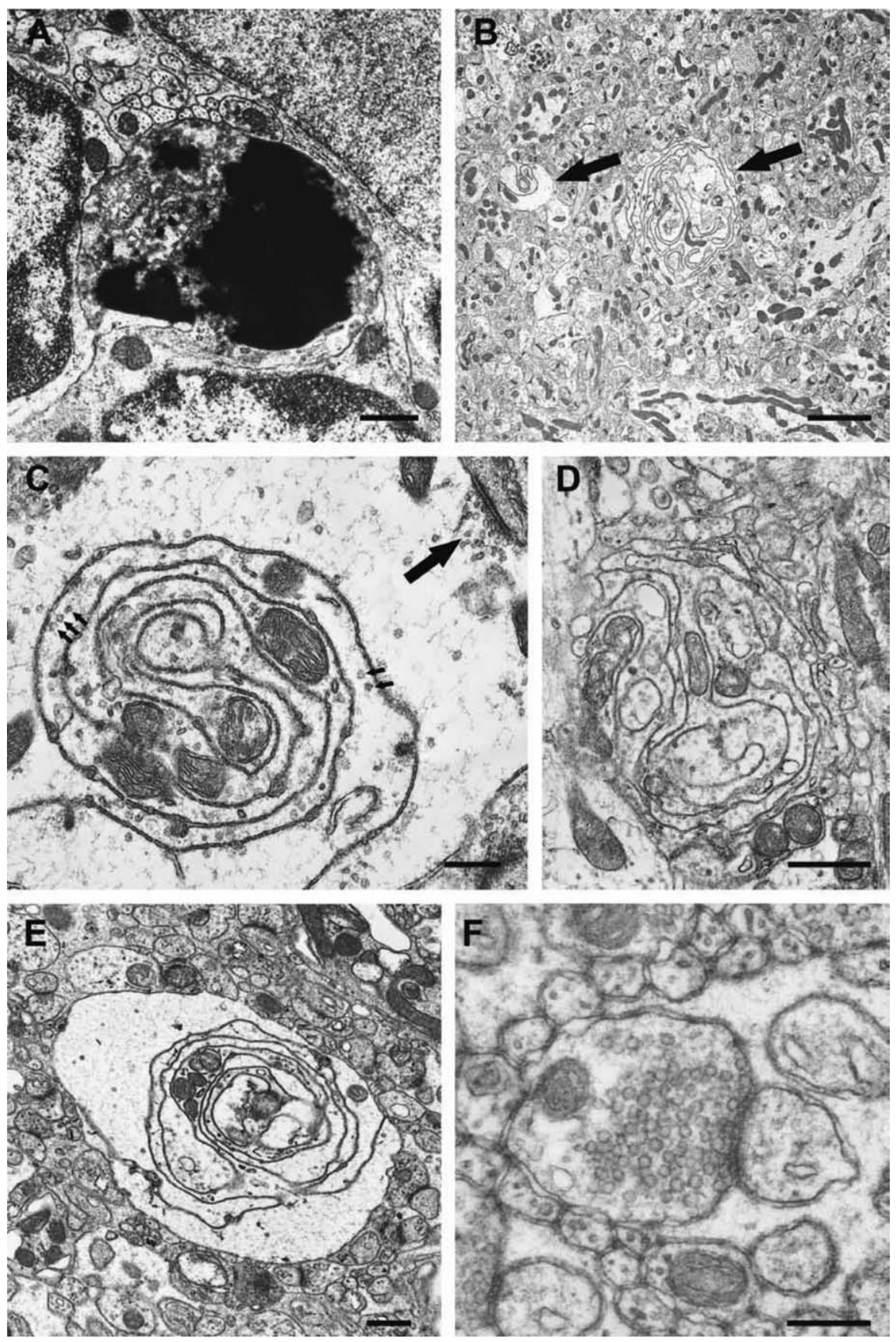

Figure 8. Ultrastructural abnormalities in $\mathrm{Tg}(\mathrm{WT}-\mathrm{E} 3)$ mice. $\boldsymbol{A}-\boldsymbol{E}$, Cerebellar sections from terminally ill $\mathrm{Tg}\left(\mathrm{WT}-\mathrm{E} 3^{+/+}\right) /$ Prnp ${ }^{0 / 0}$ mice at $494(\boldsymbol{A}-\boldsymbol{C})$ and $445(\boldsymbol{E})$ days of age, and from a $\mathrm{Tg}\left(\mathrm{WT}-\mathrm{E} 3^{+/-)} / \mathrm{Prnp}^{0 / 0}\right.$ mouse at $564 \mathrm{~d}$ of age $(\boldsymbol{D})$ were analyzed by electron microscopy. $\boldsymbol{A}, \mathrm{A}$ degenerating granule cell (center) is adjacent to two normal granule cells of which part of the nucleus and cytoplasm is seen (left and bottom). Note the fragmented, osmiophilic nucleus in the degenerating cell. $\boldsymbol{B}$, The neuropil of the molecular layer contains synaptic terminals (arrows) that are enlarged and contain redundant spiral membranous structures. $\boldsymbol{C}-\boldsymbol{E}$, Spiral membranes are seen within enlarged synaptic terminals in the molecular layer. The spiral membranes surround synaptic vesicles (small arrows in C) and mitochondria. Pre- and postsynaptic membrane specializations can be identified (large arrow in C). The cytoplasm of the enlarged synaptic endings has a clear appearance and contains floccular material. $\boldsymbol{F}$, Cerebellar section from a non-transgenic mouse at $861 \mathrm{~d}$ of age. Normal synaptic terminals containing synaptic vesicles and presynaptic membrane, as well as a postsynaptic membrane and spine, are seen. Scale bars: $200 \mu \mathrm{m}(\boldsymbol{A}) ; 500 \mu \mathrm{m}(\boldsymbol{B}) ; 50 \mu \mathrm{m}(\boldsymbol{C}) ; 100 \mu \mathrm{m}(\boldsymbol{D}, \boldsymbol{E}) ; 20 \mu \mathrm{m}(\boldsymbol{F})$.

regulated promoter to drive over-expression of wild-type human PrP specifically in skeletal muscle, a tissue that typically has a relatively low endogenous level of $\operatorname{PrP}[\sim 20 \%$ of that in brain (Chiesa et al., 2001)]. These mice developed a primary myopathy, accompanied by accumulation of weakly protease-resistant $\operatorname{PrP}$ as well as increased production of the $\mathrm{C} 1$ physiological cleavage fragment of PrP. These results demonstrate that high levels of $\mathrm{PrP}$ can produce peripheral as well as CNS pathology, a conclusion also supported by the study of Westaway et al. (1994). Consistent with this idea, preliminary histological analysis of the skeletal muscle of $\mathrm{Tg}(\mathrm{WT}-\mathrm{E} 3)$ mice revealed features indicative of muscle pathology, such as degenerating fibers, fibers with central nuclei and marked variation in size (data not shown).

Interestingly, not all mice over-expressing wild-type PrP develop a spontaneous neurological illness, as exemplified by the Tg4053 and Tg294 lines, which express murine PrP or 3F4-tagged murine PrP at 8 and 16 times endogenous levels, respectively (Telling et al., 1996; Supattapone et al., 2001). The explanation for these exceptions is unknown.

\section{Relevance to natural prion diseases}

Our data indicate that, even in the absence of artificial or disease-associated mutations, $\operatorname{PrP}$ has a measurable tendency to aggregate, and that over-expression accentuates this tendency, resulting in development of neurological disease. Aggregation of proteins induced by over-expression is a well known phenomenon, and presumably reflects saturation of cellular mechanisms such as chaperones that normally prevent protein misfolding and aggregation (Muchowski and Wacker, 2005; Hinault et al., 2006). Interestingly, small amounts of insoluble and proteaseresistant $\operatorname{PrP}$ were recently described in normal human brains at autopsy, suggesting that $\operatorname{PrP}$ may misfold and aggregate even when expressed at physiological level (Yuan et al., 2006). Thus, $\mathrm{Tg}$ (WT-E3) and related mice may be revealing a phenomenon that occurs in normal brain, but that is usually held in check by physiological processes such as chaperone-mediated refolding or proteasomal degradation. It is possible that normal aging may impair these compensatory pathways, resulting in the age-dependent increase observed for sporadic prion diseases, as well as for other neurodegenerative disorders.

\section{References}

Aguzzi A, Sigurdson C, Heikenwaelder M (2008) Molecular mechanisms of prion pathogenesis. Annu Rev Pathol 3:11-40.

Barmada S, Piccardo P, Yamaguchi K, Ghetti B, Harris DA (2004) GFP-tagged prion protein is correctly localized and functionally active in the brains of transgenic mice. Neurobiol Dis 16:527-537.

Barron RM, Campbell SL, King D, Bellon A, Chapman KE, Williamson RA, Manson JC (2007) High titers of transmissible spongiform encephalopathy infectivity associated with extremely low levels of $\operatorname{PrP}^{\mathrm{Sc}}$ in vivo. J Biol Chem 282:35878-35886. 


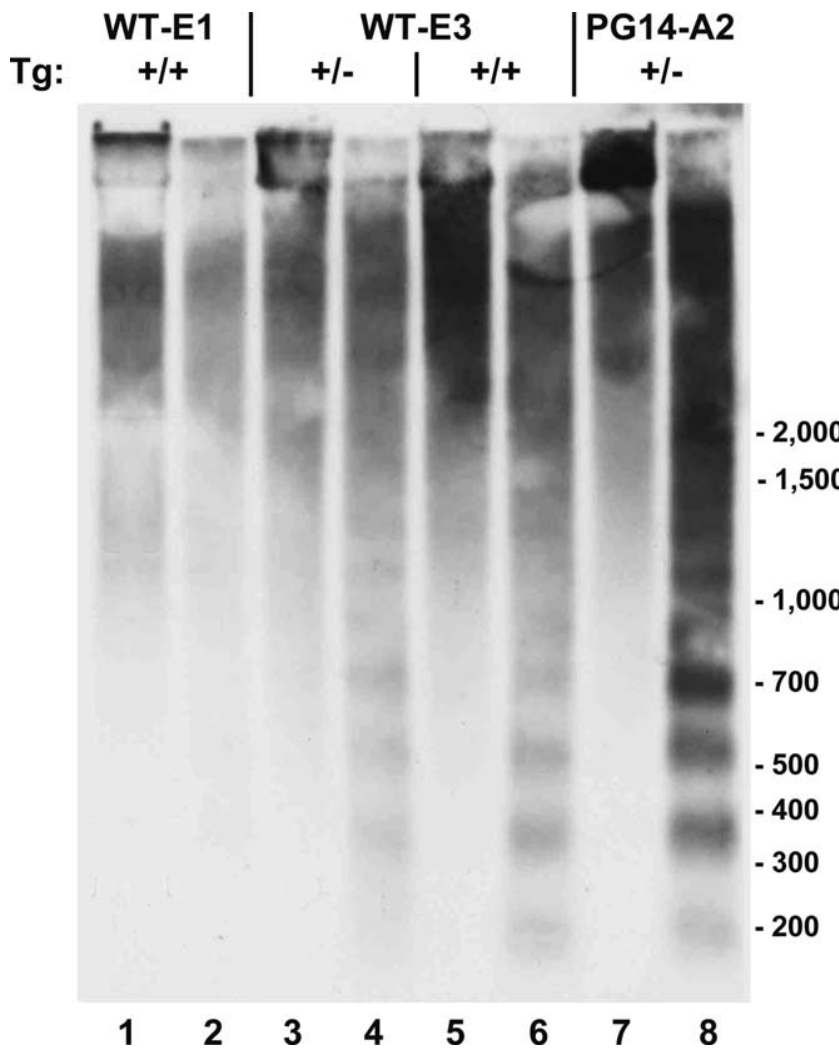

Figure 9. Cerebellar DNA from $\mathrm{Tg}$ (WT-E3) mice shows internucleosomal cleavage. Detergent extracts of cerebella were centrifuged at $16,000 \times g$, and DNA extracted from pellet fraction (lanes 1, 3, 5, and 7) and supernatant fraction (lanes 2, 4, 6, and 8) was subjected to Southern blotting using restriction-digested mouse genomic DNA as a probe. Samples were from mice of the following genotypes and ages (all on the Prnp ${ }^{0 / 0}$ background): $\operatorname{Tg}\left(\mathrm{WT}-\mathrm{E} 1^{+/+}\right.$),

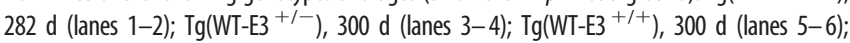
$\mathrm{Tg}\left(\mathrm{PG} 14^{+-}\right), 300 \mathrm{~d}$ (lanes $\left.7-8\right) .1 / 30$ of the DNA extracted from the pellet fractions, and the whole amount of DNA extracted from the supernatant fractions was analyzed. Size markers are given in base-pairs. Note the 200 bp ladder of DNA fragments in $\mathrm{Tg}(\mathrm{WT}-\mathrm{E} 3)$ and $\mathrm{Tg}(\mathrm{PG} 14)$ mice, but not in $\mathrm{Tg}(\mathrm{WT}-\mathrm{E} 1)$ mice.

Biasini E, Medrano AZ, Thellung S, Chiesa R, Harris DA (2008a) Multiple biochemical similarities between infectious and non-infectious aggregates of a prion protein carrying an octapeptide insertion. J Neurochem 104:1293-1308.

Biasini E, Seegulam ME, Patti BN, Solforosi L, Medrano AZ, Christensen HM, Senatore A, Chiesa R, Williamson RA, Harris DA (2008b) Noninfectious aggregates of the prion protein react with several $\mathrm{PrP}^{\mathrm{Sc}}$ directed antibodies. J Neurochem 105:2190-2204.

Brandner S, Isenmann S, Raeber A, Fischer M, Sailer A, Kobayashi Y, Marino S, Weissmann C, Aguzzi A (1996) Normal host prion protein necessary for scrapie-induced neurotoxicity. Nature 379:339-343.

Büeler H, Fischer M, Lang Y, Bluethmann H, Lipp HP, DeArmond SJ, Prusiner SB, Aguet M, Weissmann C (1992) Normal development and behavior of mice lacking the neuronal cell-surface PrP protein. Nature 356:577-582.

Chesebro B, Trifilo M, Race R, Meade-White K, Teng C, LaCasse R, Raymond L, Favara C, Baron G, Priola S, Caughey B, Masliah E, Oldstone M (2005) Anchorless prion protein results in infectious amyloid disease without clinical scrapie. Science 308:1435-1439.

Chiesa R, Harris DA (2001) Prion diseases: what is the neurotoxic molecule? Neurobiol Dis 8:743-763.

Chiesa R, Piccardo P, Ghetti B, Harris DA (1998) Neurological illness in transgenic mice expressing a prion protein with an insertional mutation. Neuron 21:1339-1351.

Chiesa R, Drisaldi B, Quaglio E, Migheli A, Piccardo P, Ghetti B, Harris DA (2000) Accumulation of protease-resistant prion protein $(\mathrm{PrP})$ and apoptosis of cerebellar granule cells in transgenic mice expressing a PrP insertional mutation. Proc Natl Acad Sci U S A 97:5574-5579.
Chiesa R, Pestronk A, Schmidt RE, Tourtellotte WG, Ghetti B, Piccardo P, Harris DA (2001) Primary myopathy and accumulation of $\operatorname{PrP}^{\mathrm{Sc}}$-like molecules in peripheral tissues of transgenic mice expressing a prion protein insertional mutation. Neurobiol Dis 8:279-288.

Chiesa R, Piccardo P, Quaglio E, Drisaldi B, Si-Hoe SL, Takao M, Ghetti B, Harris DA (2003) Molecular distinction between pathogenic and infectious properties of the prion protein. J Virol 77:7611-7622.

Chiesa R, Piccardo P, Dossena S, Nowoslawski L, Roth KA, Ghetti B, Harris DA (2005) Bax deletion prevents neuronal loss but not neurological symptoms in a transgenic model of inherited prion disease. Proc Natl Acad Sci U S A 102:238-243.

Clinton J, Forsyth C, Royston MC, Roberts GW (1993) Synaptic degeneration is the primary neuropathological feature in prion disease: a preliminary study. Neuroreport 4:65-68.

Cunningham C, Deacon R, Wells H, Boche D, Waters S, Diniz CP, Scott H, Rawlins JN, Perry VH (2003) Synaptic changes characterize early behavioural signs in the ME7 model of murine prion disease. Eur J Neurosci 17:2147-2155.

Dossena S, Imeri L, Mangieri M, Garofoli A, Ferrari L, Senatore A, Restelli E, Balducci C, Fiordaliso F, Salio M, Bianchi S, Fioriti L, Morbin M, Pincherle A, Marcon G, Villani F, Carli M, Tagliavini F, Forloni G, Chiesa $\mathrm{R}$ (2008) Mutant prion protein expression causes motor and memory deficits and abnormal sleep patterns in a transgenic mouse model. Neuron 60:598-609.

Ferrer I, Puig B, Blanco R, Marti E (2000) Prion protein deposition and abnormal synaptic protein expression in the cerebellum in CreutzfeldtJakob disease. Neuroscience 97:715-726.

Fischer M, Rülicke T, Raeber A, Sailer A, Moser M, Oesch B, Brandner S, Aguzzi A, Weissmann C (1996) Prion protein (PrP) with aminoproximal deletions restoring susceptibility of $\operatorname{PrP}$ knockout mice to scrapie. EMBO J 15:1255-1264.

Friedhoff P, von Bergen M, Mandelkow EM, Davies P, Mandelkow E (1998) A nucleated assembly mechanism of Alzheimer paired helical filaments. Proc Natl Acad Sci U S A 95:15712-15717.

Haass C, Selkoe DJ (2007) Soluble protein oligomers in neurodegeneration: lessons from the Alzheimer's amyloid beta-peptide. Nat Rev Mol Cell Biol 8:101-112.

Harris DA, True HL (2006) New insights into prion structure and toxicity. Neuron 50:353-357.

Hegde RS, Tremblay P, Groth D, DeArmond SJ, Prusiner SB, Lingappa VR (1999) Transmissible and genetic prion diseases share a common pathway of neurodegeneration. Nature 402:822-826.

Herms J, Tings T, Gall S, Madlung A, Giese A, Siebert H, Schurmann P, Windl O, Brose N, Kretzschmar H (1999) Evidence of presynaptic location and function of the prion protein. J Neurosci 19:8866-8875.

Hinault MP, Ben-Zvi A, Goloubinoff P (2006) Chaperones and proteases: cellular fold-controlling factors of proteins in neurodegenerative diseases and aging. J Mol Neurosci 30:249-265.

Huang S, Liang J, Zheng M, Li X, Wang M, Wang P, Vanegas D, Wu D, Chakraborty B, Hays AP, Chen K, Chen SG, Booth S, Cohen M, Gambetti $\mathrm{P}$, Kong Q (2007) Inducible overexpression of wild-type prion protein in the muscles leads to a primary myopathy in transgenic mice. Proc Natl Acad Sci U S A 104:6800-6805.

Jeffrey M, Halliday WG, Bell J, Johnston AR, MacLeod NK, Ingham C, Sayers AR, Brown DA, Fraser JR (2000) Synapse loss associated with abnormal PrP precedes neuronal degeneration in the scrapie-infected murine hippocampus. Neuropathol Appl Neurobiol 26:41-54.

Jeffrey M, McGovern G, Goodsir CM, Gonzalez L (2008) Strain-associated variations in abnormal PrP trafficking of sheep scrapie. Brain Pathol. Advance online publication. doi: Retrieved April 8, 2008. 10.1111/j.1750-3639.2008.00150.x

Kamenetz F, Tomita T, Hsieh H, Seabrook G, Borchelt D, Iwatsubo T, Sisodia S, Malinow R (2003) APP processing and synaptic function. Neuron 37:925-937.

Kascsak RJ, Rubenstein R, Merz PA, Tonna-DeMasi M, Fersko R, Carp RI, Wisniewski HM, Diringer H (1987) Mouse polyclonal and monoclonal antibody to scrapie-associated fibril proteins. J Virol 61:3688-3693.

Lashuel HA, Petre BM, Wall J, Simon M, Nowak RJ, Walz T, Lansbury PT Jr (2002) $\alpha$-synuclein, especially the Parkinson's disease-associated mutants, forms pore-like annular and tubular protofibrils. J Mol Biol 322:1089-1102.

Lehmann S, Harris DA (1995) A mutant prion protein displays an aberrant 
membrane association when expressed in cultured cells. J Biol Chem 270:24589-24597.

Li A, Christensen HM, Stewart LR, Roth KA, Chiesa R, Harris DA (2007) Neonatal lethality in transgenic mice expressing prion protein with a deletion of residues 105-125. EMBO J 26:548-558.

Mallucci G, Dickinson A, Linehan J, Klöhn PC, Brandner S, Collinge J (2003) Depleting neuronal $\mathrm{PrP}$ in prion infection prevents disease and reverses spongiosis. Science 302:871-874.

Mallucci GR, Ratté S, Asante EA, Linehan J, Gowland I, Jefferys JG, Collinge J (2002) Post-natal knockout of prion protein alters hippocampal CA1 properties, but does not result in neurodegeneration. EMBO J 21:202-210.

Manson JC, Clarke AR, Hooper ML, Aitchison L, McConnell I, Hope J (1994) 129/Ola mice carrying a null mutation in PrP that abolishes mRNA production are developmentally normal. Mol Neurobiol 8:121-127.

Marchut AJ, Hall CK (2006) Spontaneous formation of annular structures observed in molecular dynamics simulations of polyglutamine peptides. Comput Biol Chem 30:215-218.

Medrano AZ, Barmada SJ, Biasini E, Harris DA (2008) GFP-tagged mutant prion protein forms intra-axonal aggregates in transgenic mice. Neurobiol Dis 31:20-32.

Muchowski PJ, Wacker JL (2005) Modulation of neurodegeneration by molecular chaperones. Nat Rev Neurosci 6:11-22.

Nazor KE, Kuhn F, Seward T, Green M, Zwald D, Pürro M, Schmid J, Biffiger K, Power AM, Oesch B, Raeber AJ, Telling GC (2005) Immunodetection of disease-associated mutant $\mathrm{PrP}$, which accelerates disease in GSS transgenic mice. EMBO J 24:2472-2480.

Pankiewicz J, Prelli F, Sy MS, Kascsak RJ, Kascsak RB, Spinner DS, Carp RI, Meeker HC, Sadowski M, Wisniewski T (2006) Clearance and prevention of prion infection in cell culture by anti-PrP antibodies. Eur J Neurosci 23:2635-2647.

Piccardo P, Manson JC, King D, Ghetti B, Barron RM (2007) Accumulation of prion protein in the brain that is not associated with transmissible disease. Proc Natl Acad Sci U S A 104:4712-4717.

Prusiner SB (1998) Prions. Proc Natl Acad Sci U S A 95:13363-13383.

Prusiner SB (2004) Prion biology and diseases, 2nd Ed. Cold Spring Harbor, New York: Cold Spring Harbor Laboratory.

Shankar GM, Li S, Mehta TH, Garcia-Munoz A, Shepardson NE, Smith I, Brett FM, Farrell MA, Rowan MJ, Lemere CA, Regan CM, Walsh DM,
Sabatini BL, Selkoe DJ (2008) Amyloid-beta protein dimers isolated directly from Alzheimer's brains impair synaptic plasticity and memory. Nat Med 14:837-842.

Solforosi L, Criado JR, McGavern DB, Wirz S, Sánchez-Alavez M, Sugama S, DeGiorgio LA, Volpe BT, Wiseman E, Abalos G, Masliah E, Gilden D, Oldstone MB, Conti B, Williamson RA (2004) Cross-linking cellular prion protein triggers neuronal apoptosis in vivo. Science 303:1514-1516.

Supattapone S, Muramoto T, Legname G, Mehlhorn I, Cohen FE, DeArmond SJ, Prusiner SB, Scott MR (2001) Identification of two prion protein regions that modify scrapie incubation time. J Virol 75:1408-1413.

Telling GC, Haga T, Torchia M, Tremblay P, DeArmond SJ, Prusiner SB (1996) Interactions between wild-type and mutant prion proteins modulate neurodegeneration in transgenic mice. Genes Dev 10:1736-1750.

Townsend M, Cleary JP, Mehta T, Hofmeister J, Lesne S, O'Hare E, Walsh DM, Selkoe DJ (2006) Orally available compound prevents deficits in memory caused by the Alzheimer amyloid-beta oligomers. Ann Neurol 60:668-676.

Tremblay P, Ball HL, Kaneko K, Groth D, Hegde RS, Cohen FE, DeArmond SJ, Prusiner SB, Safar JG (2004) Mutant PrP ${ }^{\text {Sc }}$ conformers induced by a synthetic peptide and several prion strains. J Virol 78:2088-2099.

Walsh DM, Klyubin I, Fadeeva JV, Cullen WK, Anwyl R, Wolfe MS, Rowan MJ, Selkoe DJ (2002) Naturally secreted oligomers of amyloid beta protein potently inhibit hippocampal long-term potentiation in vivo. Nature 416:535-539.

Westaway D, DeArmond SJ, Cayetano-Canlas J, Groth D, Foster D, Yang SL, Torchia M, Carlson GA, Prusiner SB (1994) Degeneration of skeletal muscle, peripheral nerves, and the central nervous system in transgenic mice overexpressing wild-type prion proteins. Cell 76:117-129.

Westergard L, Christensen HM, Harris DA (2007) The cellular prion protein $\left(\operatorname{PrP}^{\mathrm{C}}\right)$ : its physiological function and role in disease. Biochim Biophys Acta 1772:629-644.

Yuan J, Xiao X, McGeehan J, Dong Z, Cali I, Fujioka H, Kong Q, Kneale G, Gambetti P, Zou WQ (2006) Insoluble aggregates and proteaseresistant conformers of prion protein in uninfected human brains. J Biol Chem 281:34848-34858.

Zanusso G, Liu D, Ferrari S, Hegyi I, Yin X, Aguzzi A, Hornemann S, Liemann S, Glockshuber R, Manson JC, Brown P, Petersen RB, Gambetti P, Sy MS (1998) Prion protein expression in different species: analysis with a panel of new mAbs. Proc Natl Acad Sci U S A 95:8812-8816. 